for highly trained personnel for its successful application; and there seems little reason why this in its turn should not in due course be placed upon an electrical basis. Some lack of accord between pure tone threshold tests and intelligibility in the earlier stages of deafness is recognized and accords with the more empirical observations of clinicians. One of the best chapters is that which describes deafness and its recognition in the young child. The influence of Mr. T. S. Littler's technical contributions is apparent throughout this book and is frequently acknowledged by its authors.

C. S. H.

\section{Biography of the Unborn}

By Margaret Shea Gilbert. Pp. $\mathrm{x}+132$. (London : John Murray, 1939.) 5s. net.

7 HIS little book surveys in simple language the development of the human embryo during its nine months of intra-uterine life. Fertilization, the role of the sex chromosomes, the genesis of twins and the occurrence of malformations are also briefly dealt with. The descriptions are illustrated with numerous diagrams which clearly depict the changes that occur as growth proceeds from month to month.

The book gives an accurate summary of the subject, but is scarcely advanced enough or sufficiently scientific for the student or medical practitioner. For the layman who is interested in the subject, and for whom it is primarily intended, it can be recommended.

\section{Metallurgy}

Metallurgy for Engineers

By E. C. Rollason. Pp. viii + 272. (London : Edward Arnold and Co., 1939.) 10s. net.

TO words are wasted in this book, the purchaser 1 of which receives about seven hundred per penny, together with some 150 illustrations, including many clever diagrams which amplify the text. Here indeed is value for money which no student can readily ignore. The most serious criticism which can be made of the book is that it is too concise and may encourage 'cramming'. Although the preface indicates that the book is intended for use in conjunction with a teacher, this does not absolve the author from responsibility, and one would like to see, in the next edition, fewer statements of fact and more explanations of basic principles.

\section{Practical Microscopical Metallography}

By Dr. Richard Henry Greaves and Harold Wrighton. Third edition, revised and enlarged. Pp. xi $+272+60$ plates. (London : Chapman and Hall, Ltd., 1939.) 18s. net.

A DISTINGUTSHED research metallurgist collatA orated with a virtuoso of the metallographic microscope to produce, in 1924, the first edition of this book. It has become the standard work on the subject, and one turns from the second edition with a tinge of regret, to greet the new friend. The authors still refuse to call it a text-book, although it is far more than a series of annotated photomicrographs. Many of these are, as in the previous editions, superb, and most of them are excellent : one or two permit the average metallographer to regain his self-respect, at least for a moment. The descriptions of technique are even more extensive and the practical hints on low-power work are particularly welcome. Discussion of the 'austemper' process, photomicrographs of typical disintegration-proof 18-8 steels, and particulars of the electrolytic cyanide etch for precipitated carbides, might be included with advantage in the next edition.

\section{MisCELlaNY}

The Growth of Science

An Outline History. By A. P. Rossiter. (Published for the Orthological Institute.) Pp. 372. (London : Sir Isaac Pitman and Sons, Ltd., 1939.) 5s. net.

7 HIS little book will prove very useful from many points of view. It gives an authoritative account of the leading stages of the history of science. Then it connects the various fields of science in a way which helps the reader to understand the unity of its development. Moreover, it gives a short explanation of the notions involved in the problems discussed. Finally, it gives a good illustration of what can be done in this field by a judicious use of Basic English. Controversial issues are wisely avoided; and as the book is short, one feels less the monotony of the basic vocabulary and syntax ably used by the author. In itself, this work is an excellent popular introduction to the history of science.

\section{The Language of Gesture}

By Dr. Macdonald Critchley. Pp. 128. (London: Edward Arnold and Co., 1939.) 5s. net.

A $\mathrm{S}$ students of human speech still concentrate A primarily on its sounds rather than on the muscular movements which produce them, it is well that specialists like Dr. Macdonald Critchley should intervene. He has brought together, in 124 pages, a larger volume of valuable material than has so far been available. It is surprising, however, that though the author pays great attention to gesture languageincluding copious references to the scattered literature on the subject-he does not mention Darwin's observation on the sympathy of movement between man's hand and mouth, which constitutes the fundamental link between primitive descriptive gesture and the significant mouth movements of speech. Nor does he clearly define the difference between instinctive pantomime-such as that of the born deaf-which describes events as a whole, and the acquired sign languages-such as that of the Red Indians-in which each sign stands for a separate unit of thought, equivalent to a 'word'. The origin of these units of thought deserves thorough investigation.

The reference to Armenian sign language (p. 50) needs correction. The language is used exclusively by women-not by men. The descriptions of hand 